\title{
Review Article \\ The Status and Future Prospects of Hydropower for Sustainable Water and Energy Development in Tanzania
}

\author{
Baraka Kichonge \\ Mechanical Engineering Department, Arusha Technical College (ATC), P.O. Box 296, Arusha, Tanzania \\ Correspondence should be addressed to Baraka Kichonge; kichonge@yahoo.com
}

Received 7 January 2018; Accepted 8 March 2018; Published 6 May 2018

Academic Editor: Wei-Hsin Chen

Copyright ( 2018 Baraka Kichonge. This is an open access article distributed under the Creative Commons Attribution License, which permits unrestricted use, distribution, and reproduction in any medium, provided the original work is properly cited.

\begin{abstract}
Tanzania is among the countries with the fastest growing economy in Africa and therefore the need for affordable, clean, and most importantly sustainable electrical energy to meet her ever growing demands is pressing. In recent years, the country's electricity needs have been largely dominated by thermal generations despite the fact that Tanzania is gifted with huge hydropower resource potential approximated at $38,000 \mathrm{MW}$ with only a very small portion exploited to date. However, the exploited potential is expected to grow by commissioning of identified large and medium-scale hydropower projects with a total installed capacity of 4,765 MW currently under various stages of implementation. Moreover, the geographical location of Tanzania has several benefits to support development of small hydropower projects essential for appropriate utilization of available water resources as a way of mitigating climate challenges effects. Over the last decade, the country electricity demand along with end-use of energy has witnessed significant increases as economic development spreads towards achieving Vision 2025 goals. Proposed hydropower developments are projected to have enormous benefits in the acceleration of economic growth while contributing to greenhouse gas emissions reduction. In this paper, hydropower, which is one of the domestic options for clean energy development path, its present and future potential status, and water resources are explored based on a comprehensive review of energy sector relevant documents and polices.
\end{abstract}

\section{Introduction}

Access to clean, affordable, and reliable energy coupled with its impact on mitigating the drastic effects of climate change due to human activities is one of this era's most serious concerns in the quest for increasing prosperity through sustainable economic growth. Energy access is important to achieving sustainable development goals. The country's strategy is to accomplish electrification rate of more than 75 percent by the year 2033 with the focus on the transport and industrial sectors $[1,2]$. Therefore, it can be noted that, in order to sustain the continually growth in an annual electricity demand, the indigenous renewable energy resources ought to be included in the pursuit of sustainable energy alternatives. This gives a determined motivation to investigate the potential of hydropower as a renewable energy source, which is yet to be fully exploited. Current hydropower technologies are able to convert more than $90 \%$ of the available energy into electricity as compared to the efficiencies ranges of $30 \%-50 \%$ for thermal-power plants and other similar technologies [3, 4]. Hydropower continues to remain the most efficient technology for electricity generation with the expectations of further improvements in future $[5,6]$.

In pursuing her quest to attain a middle-income economy status as envisioned in its Development Vision 2025, Tanzania faces huge tasks of meeting energy needs due to the high expectations in growth to fuel the economy and at the same time minimize environmental challenges $[1,7,8]$. Providing affordable and reliable energy specifically electricity, is characterized as an important function of any country's economic sectors $[9,10]$. Past decades have witnessed the actual electricity sector falls short of the required level of reliability, despite abundant hydroenergy potential available in the country. Lack of a reliable energy supply as expounded in URT [11] was recognized as the main binding constraint to economic development. Realizing solutions to meeting electricity demands while minimizing environmental challenges, requires long-term and firm actions for sustainable 
economic development. In this paper, hydropower which is one of the domestic options for clean energy development path, its present and future potential status, and the water resources are investigated in detail for Tanzania based on a comprehensive review of energy sector relevant documents and polices.

\section{Hydropower: Renewable and Sustainable Energy Resource}

Energy renewability relates to the concept of energy being extracted from a resource and replaced with the same amount on a comparable time-scale as that of its extraction. Renewability is a direct response to uncertainties of energy supplies owing to possible interruptions and subsequent depletion of primary sources $[15,16]$. Renewables are considered as carbon-neutral and inexhaustible energy resources encompassing varieties of fuel types and usages with minimum secondary wastes productions $[17,18]$. Renewables are also described as one of the most efficient and effective solutions to environmental challenges as compared to nonrenewable sources [19-22]. Hydropower is accepted as renewable energy resource and worthy of international support [23, 24]. Hydropower utilizes water for electricity generation without depleting it and therefore helps in contribuing to fresh water sustainability for other downstream applications. Hydropower is the only indigenous renewable energy resource in Tanzania whose role in electricity generation is significantly greater than any other renewables $[7,12]$.

The concept of sustainability in development is welldefined by World Commission on Environment and Development (WCED) as the "ability to make development sustainable and to ensure that it meets the needs of the present without compromising the ability of future generations to meet their own needs" [30,31]. Sustainability is considered as a direct response to deteriorating environmental quality coupled to a growing energy resource demands under depletion threat as a result of populations growth and living standards improvement [15]. Hydropower as is the case for other renewables is recognized as viable option for sustainable developments because of its enormous potential and positive impact on the environment resulting in much lesser health and global climate change risks [18, 32, 33] (Panwar et al., 2014). Hydropower has obvious benefits directly linked not only to electrical energy production but also to water management to support sustainable socioeconomic development and therefore will continue to remain with a unique role to play in the foreseeable future. For example, hydropower dams, reservoirs, and other infrastructures offer exclusive management of fresh water storage and transportation and thus help fight climate change effects to the surrounding communities.

With the obvious population growth in the coming years likely to be shifting from rural to urban areas, the need for sustainable energy solution in Tanzania will be ever more pressing. As hydropower is adaptive and flexible, it is set apart from other renewable and nonrenewable energy resources and therefore the best option for sustainability [5]. Harnessing of hydropower as renewable energy resource appears to be a promising solution for improving the quality of life in rural areas where access to commercial energies is a challenge $[18,19,34]$. As dealt with by several scholars and summarized in Figure 1, renewable energy touches all aspects of life including but not limited to socioeconomic, political, environmental, and technological, thus an intimate connection to sustainable development $[6,19,35]$.

\section{Water Sustainability in Tanzania}

3.1. Geographical Location and General Climate. Tanzanian is located in Eastern Africa region south of the equator. The country is characterized with a tropical climate and significant regional topographical variation. Large part of Tanzania is categorized as highland with the exceptional of narrow coastal strip. The climate varies from tropical along the coast to temperate in the highlands. The highland temperatures are around $20-23^{\circ} \mathrm{C}$ throughout the year and are characterized by unimodal and bimodal seasonal rainfall distribution $[36,37]$. The primary drivers of seasonal rainfall in Tanzania are categorized as intertropical convergence zone migration, narrow belt of very low pressure, and heavy precipitation forming near the earth equators [38]. The bimodal seasonal rainfall occurs in the coastal belt, the northeastern highlands, and along Lake Victoria and is comprised of the short rainfall from October-December and the long rains fall from March to June. The unimodal seasonal rainfall regularly occurs from October to November to April in the central, southern, and south-western highlands of the country $[38,39]$.

3.2. Water Policy and Resource Management. Water is a basic natural resource sustaining life and provides for countless socioeconomic needs for development [40, 41]. Tanzanian water resource management and governance is divided into nine hydrological water basins through Act No. 10 of 1981 [42]. Seven out of these nine basins are transboundary including Lake Victoria basin jointly owned with Kenya and Uganda; Lake Tanganyika basin jointly shared with DR Congo, Zambia, and Burundi; Lake Nyasa Basin jointly owned with Malawi and Mozambique; Lake Rukwa basin jointly owned with Zambia; Ruvuma River Basin jointly owned with Mozambique and Malawi; along with the Central Drainage Basin and Pangani River Basin both jointly owned with Kenya [43-45]. Water resource management at the national level is principally managed by recognized institutions such as policies, acts, and legislations and other interrelated organizations that are judiciously established in accordance with the formal provisions $[42,46]$.

The primary goal of the National Water Policy (2002) was to formulate a comprehensive framework to ensure sustainable utilization and management of the country's huge water resources potential [47]. The policy intends to ensure that its beneficiaries take full responsibilities in all stages of water resource development. National Water Policy (2002) recognizes important link between Tanzanian water resources, socioeconomic development, and environmental requirements in achieving Vision 2025 goals [47, 48]. The policy further explicates the vital role in which water 


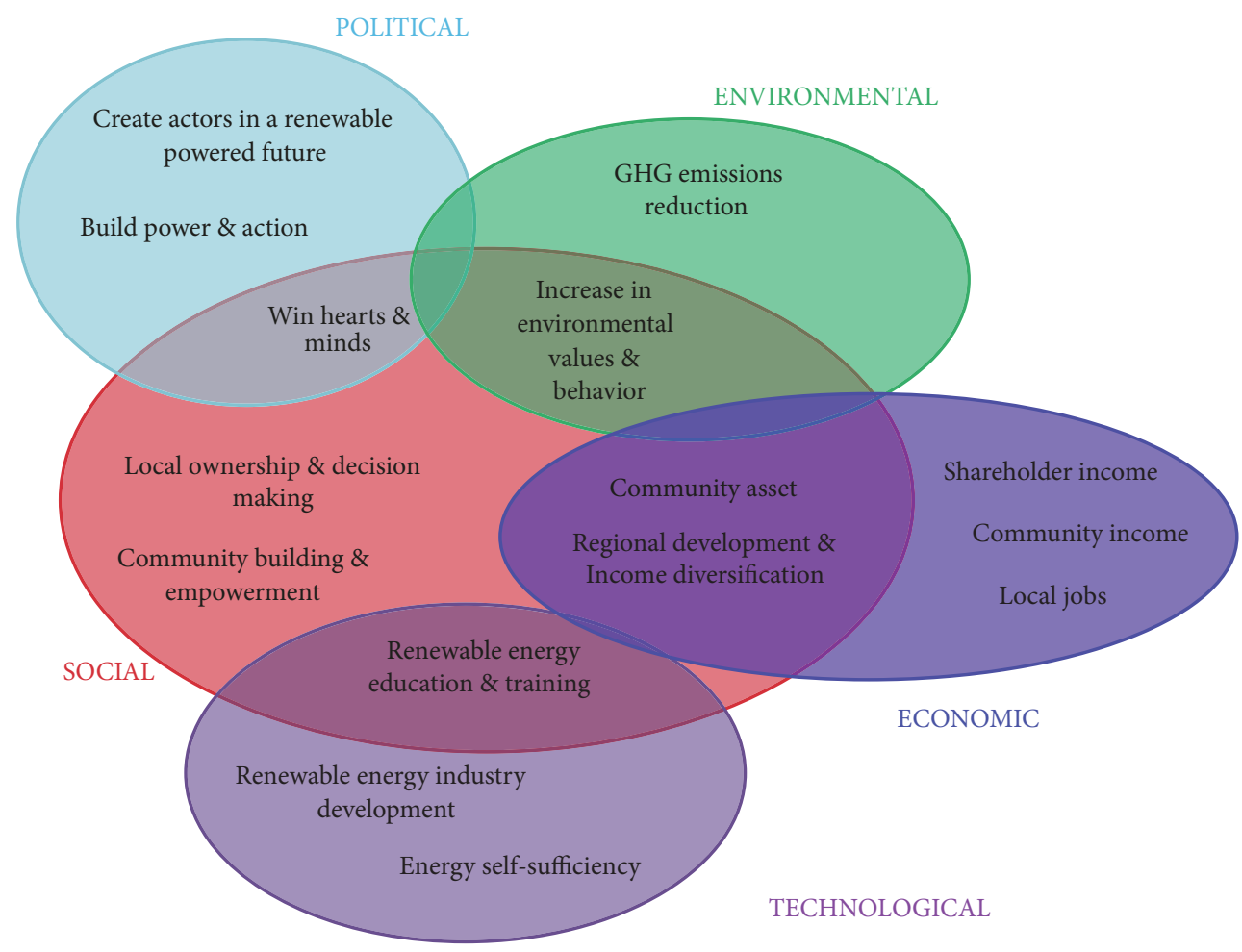

FIGURE 1: Renewables for sustainable development [6].

contributes towards various economics activities including energy and transboundary requirements. In view of this, the National Water Policy (2002) demands for an integrated water resource management approach to ensure unbiased sustainable utilization and management of water resources for both socioeconomic development and the environment maintenance [49].

3.3. Water Availability and Flow. When in its natural state, water is considered as an integral part of the environment whose quantity and quality govern in what manner it can be used. Being a water-rich country, Tanzania is endowed with lakes, river, and water basins that originate from the highlands parts of the country as depicted in Figure 2 [50]. These water resources if sustainably exploited and managed would provide a bright future in terms of hydropower generation and also revenue from economic activities such as tourism and irrigation [7, 51]. A third of the country's water resources are located in highland areas with precipitation in excess of $1000 \mathrm{~mm}$ whereas the other third of the country is semiarid with rainfall of less than $800 \mathrm{~mm}$ [52].

Groundwater is among the vital sources of water in most of areas in Tanzania. Groundwater primarily controlled by geology and climate is variable, an important supplement source of surface water in semiarid water scarce areas of Tanzania accounting for more than $25 \%$ of all domestic needs $[47,53,54]$. The rainfall supports and sustains the groundwater level with rivers being the main surface water resource available in Tanzania. The major waterway system provides the vital surface water resources with mean yearly run-off of 83 billion cubic metres and an estimated ground

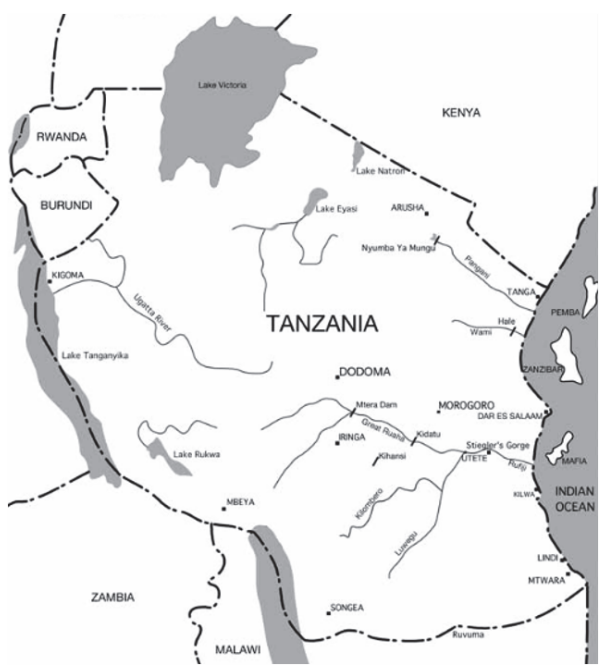

FIGURE 2: Tanzania’s key water ways and lakes [25].

water recharge of 3.7 billion cubic metres. Around fifty per cent of the surface run-off water flows towards Indian Ocean through Pangani, Wami, Ruvu, and Rufiji among other rivers systems with the balance flowing north-ward, into Lake Victoria, west-ward, into Lake Tanganyika, and south-ward, into Lake Nyasa $[52,55]$.

\section{Hydropower in Tanzania}

4.1. Hydropower Resource Potential. The history of hydropower generation in Tanzania dates back to the colonial era, 


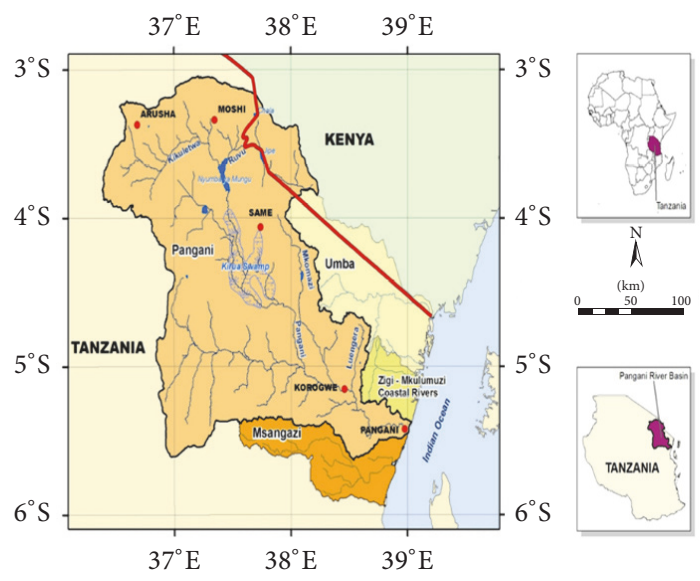

Figure 3: Pangani river basin [26].

where most of the operational small hydropower plants were installed through the efforts of missionaries. The installation of small hydropower plants was realized as a result of the natural topographic features which offer the country with plentiful opportunities for hydropower resources. Tanzania has a relatively plentiful hydropower potential as a result of its inland part being at high elevation from sea level and therefore precipitous rivers availability. The total hydropower resource potential is approximated at $38,000 \mathrm{MW}$ equivalent to $190,000 \mathrm{GWh} /$ year $[2,7]$. The potential hydropower resources as depicted in Figure 2 are mainly located in the rift valley escarpments in the West, South West, and North East with very little being accounted in the central part of the country due to relatively flat features and dry seasons [56].

4.2. Rufiji and Pangani Basins. Rufiji and Pangani basins gutter water from the "Eastern Arc Mountains" and their neighbouring lowlands and thereafter stream to the Indian Ocean $[57,58]$. Pangani river basin is a transboundary shared by Tanzania and neighbouring country Kenya. Tanzanian part of Pangani river basin occupies an estimated 56,300 square kilometres equivalent to $95 \%$ of the whole basin [57, 59, 60]. Pangani river basin as depicted in Figure 3 is formed as a series of small streams draining from Mt. Kilimanjaro, Mt. Meru, the Pare and Usambara Mountain ranges and the springs emerging from Kenya. These streams join to create the main Pangani river and flow into the Indian Ocean at the coastal town of Pangani [61-63]. Pangani river basin climate is generally closely related to topography with flatter lowland southwest half of the basin being semiarid, whereas the mountain ranges are cooler and wetter with the highaltitude slopes above Mt. Meru and Mt. Kilimanjaro receiving rainfall of more than $2500 \mathrm{~mm}$ annually $[62,64,65]$. Pangani river basin is characterized with two distinct seasons, the first one being rainy season occurring between March and May and the second one being dry season occurring during the rest of the year [65].

Pangani river basin collects an annual rainfall approximated at $34.77 \times 10^{9}$ cubic metres out of which fifty-five percent originates from Mt. Kilimanjaro highlands. The 500kilometre-long river serves a series of hydropower plants

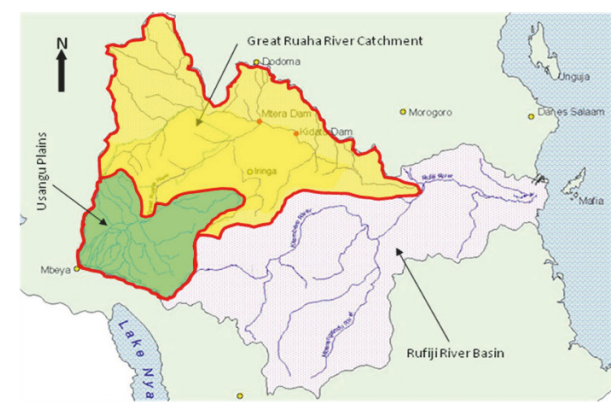

FIGURE 4: Rufiji basin and its rivers network [27].

namely Nyumba ya Mungu, Hale, and New Pangani falls, which when combined were once contributing approximately $17 \%$ of Tanzania's national electricity demands before the introduction of domestically available natural gas fired power plants in the year $2000[66,67]$. All of the Pangani river hydropower plants are sited downstream of main water users. Nyumba ya Mungu dam receives mean annual flow of roughly $43 \mathrm{~m}^{3}$ per second with varied outflow of $15-25 \mathrm{~m}^{3}$ per second of which 5 to $8 \mathrm{~m}^{3}$ per second is lost due to evaporation, transpiration, and consumptive usage between the dam and Hale hydropower plant. Groundwater potential in the basin is high in the volcanic and coastal aquifers with $88 \%$ of abstraction being used for irrigations purposes [68]. The Pangani river basin is considered as water stressed ascribed by high population growth and climate change among other factors $[65,68,69]$.

The Rufiji river basin depicted in Figure 4 is an extensive area of land that includes mountains, savanna woodlands, farmland areas, and extensive wetlands which spreads across the southern part of Tanzania [57, 70, 71]. The Rufiji river basin is the largest of the nine river basins in Tanzania which covers about $178,000 \mathrm{~km}^{2}$ equivalent to $20 \%$ of the total land and is characterized with varied topography rising from sea level in the east to approximately 3,000 metres above sea level in the west $[44,57,72]$. The Great Ruaha river catchment which is part of Rufiji river basin, covers an area of approximately to $68,000 \mathrm{~km}^{2}$, and encompasses the Usangu area, which has a total area of $20,811 \mathrm{~km}^{2}$ in the southwestern part of the country $[52,72,73]$. The Great Ruaha river catchment got its name from the Great Ruaha river which is among the significant rivers in the basin. The Great Ruaha river originating from the Usangu highlands is the main supplier of water in the Great Ruaha river catchment. The Great Ruaha river flows into the Usangu plains and wetland through to the Ruaha National Park and provides $56 \%$ of runoff to Mtera hydropower plant while the remaining balance is from little Ruaha river (18\%) and Kisigo River (26\%) [73].

The Great Ruaha is a multifaceted basin with mixed multisectoral water applications for sustained irrigation, power generation, and other water-related livelihoods such as fishing and livestock keeping [74, 75]. Primary activities in the basin include irrigation of high-valued crops such as rice and are located in the upstream from the main hydropower plants [76-78]. The Great Ruaha river basin 
supports extensively ecological necessities for the Ruaha National Park and it is a significant tributary of the Rufiji river $[79,80]$. Economically, the Great Ruaha river basin is one of the utmost important waterways hosting more than fifty percent of the present country's hydropower capacity $[73,78,81]$. Concerns over water availability remains as the topmost challenge at the basin stirred by repeated water shortages at Mtera hydropower plant which is the largest dam in the country considering height, crest length, and concrete volume $[7,82]$.

\subsection{Effects of Climate Change on Hydropower Generations.} Climate is an important factor in determination of the amount of water flowing through the water-cycle [83]. Global warming and the corresponding growth in the world annual temperature have weakened the natural way in which the earth normalises its climate, thus affecting water resource availability as a result of seasonal rainfall cycles [84]. The rivers feeding Pangani and the Great Ruaha basins have irregular regimes with the average annual precipitation, evaporation, and surface run-off greatly varying geographically depending on whether it is dry or wet season. Observed rainfall over Tanzania as described in McSweeney et al. [38], MEM [7], and Paavola [85] depicts statistically considerable annual decreasing trends of up to $17 \%$ over the past decade. The decreasing trend in rainfalls is further shown to affect June, July, August, and September (JJAS) and March, April, and May (MAM) rainfall seasons with the decrease in annual rainfall observed to be at an average of $2.8 \mathrm{~mm}$ per month equivalent to 3.3 percent per decade affecting the most southern part of Tanzania. MAM and JJAS rainfall decreases are recorded at $4.0 \mathrm{~mm}(3.0 \%)$ and $0.8 \mathrm{~mm}(6.0 \%)$ per month per decade, respectively. Notwithstanding efforts to mitigate climate change effects, reduced precipitation and increased evaporation are anticipated to increase in future and therefore water security problems in water-stressed areas of Southern African will be increased [86, 87]. Subsequently, authorized and unlawful water abstractions from rivers and reservoirs is expected to increase limiting water availability for electricity generations.

Climate change in numerous previous dry years was able to negatively impact the country's ability to provide stable electricity based on hydropower sources [86, 88, 89]. According to recent spatiotemporal distribution of rainfall analysis done by Loisulie [88], the extremely dry years from 1979 to 2009 were recorded to be 2000, 2001, 2003, 2005, 2007, and 2009 as well as in 2015. Dry weathers years resulted in draughts causing reduced water supply which in turn caused hydropower plants generation as low as $140 \mathrm{MW}$ from the installed capacity of $561 \mathrm{MW}$ in 2006 . Drought and floods are known to bring extreme weather events which undesirably affects hydropower generation and thus increase operational costs, reduce water quantity and quality, and cause destructions to infrastructure $[84,90]$.

4.4. Hydropower: Deployment Challenges and Benefits. Hydropower is differentiated from other electricity generating sources including some renewables because of its negative and positive effects that it can have on the environment.
Large- and medium-scale hydropower plants development often result in environmental challenges [91] along with socioeconomic conflict, largely in the case of storage-based hydropower plants [92]. Hydropower plants, dams, and reservoirs construction extends well beyond from direct effects on environment to take in forced human and animal populations resettlements, competition for water usage among power generating plants owners and neighbouring communities. and expanding deforestation associated with new infrastructures such as roads [84, 93]. Human populations resettlements from the dam, reservoir, and other infrastructures in the constructions areas is unquestionably the utmost challenging socioeconomic feature of hydropower that might possibly result in ethical issues to ensure that the rights of affected communities are legally respected.

Despite these challenges, there are hydropower socioeconomic benefits left for the future generation which include access roads, dam, and reservoirs. Dam and reservoirs are often used to collect, store, and manage water needed for economic activities other than electrical energy generation. Hydropower as a sustainable resource can be deployable in a decentralized and modular manner to improve grid stability and to support the utilization of other intermittent renewable energy sources such as wind and solar power [92]. This makes hydropower appropriate energy source for both large-scale and small grids and off-grid solutions, thus perfect for power supply in rural off-grid regions in which connection to the national grid is either excessively expensive or technically difficult to accomplish $[84,94]$.

\section{Hydropower Market and Development in Tanzania}

5.1. Energy Consumption and Emissions in Tanzania. Annual greenhouse gas (GHG) emissions as a result of energy consumptions continue to rise at the time the country strives to meet her ever increasing demand for electricity and transport fuels. Tanzanian GHG emissions specifically $\mathrm{CO}_{2}$ emissions from fossil fuels have grown phenomenally since 1971 to date. $\mathrm{CO}_{2}$ in Tanzania has been virtually constant for the years 1971-1990 and begun to increase sharply in 2000 to 2015 as depicted in Figure 5. The growth in $\mathrm{CO}_{2}$ emissions has arisen largely due to the increased burning of coal and oil. The growth of $\mathrm{CO}_{2}$ emissions as a result of fuel combustion between 1990 and 2015 is equivalent to $595.6 \%$ change. The emission for 2015 was estimated at 11.62 million tonnes of $\mathrm{CO}_{2}$ in which 7 million tonnes of $\mathrm{CO}_{2}$ and 2.8 million tonnes of $\mathrm{CO}_{2}$ were generated through various activities in "Electricity and Heat Production" and "Transports" sectors, respectively $[12,13]$. Despite this growth, $\mathrm{CO}_{2}$ emissions and other energy indicators for Tanzania as compared to other countries, for example, Kenya and South Africa, are low in both absolute terms and per capita as depicted in Table $1[12,13]$.

5.2. The Role of Hydropower within Primary Energy Supply. In 2015, hydropower accounted for $0.70 \%$ of the country's total primary energy supply which was equivalent to 25,968 kilo tonnes of oil equivalent (kTOE). As can be seen in Table 2, this is against $1.37 \%$ for the years 1990 and 2000 in 
TABLE 1: Key energy indicators statistics for 2015.

\begin{tabular}{|c|c|c|c|}
\hline Indicator & Tanzania & Kenya & South Africa \\
\hline $\begin{array}{l}\text { Total energy supply (TPES) } \\
\text { (millions of tonnes of oil equivalent) }\end{array}$ & 25.97 & 25.10 & 142.03 \\
\hline $\begin{array}{l}\mathrm{CO}_{2} \text { emissions } \\
\text { (millions of tonnes of } \mathrm{CO}_{2} \text { ) }\end{array}$ & 11.62 & 14.14 & 427.57 \\
\hline $\begin{array}{l}\mathrm{CO}_{2} / \text { population } \\
\text { (tonnes of } \mathrm{CO}_{2} \text { per capita) }\end{array}$ & 0.22 & 0.31 & 7.77 \\
\hline $\begin{array}{l}\mathrm{CO}_{2} / \mathrm{TPES} \\
\text { (tonnes of } \mathrm{CO}_{2} \text { per tonne of oil equivalent) }\end{array}$ & 0.45 & 0.56 & 3.01 \\
\hline $\begin{array}{l}\text { Electricity consumption per population } \\
\text { (MWh/capita) }\end{array}$ & 0.1 & 0.17 & 4.125 \\
\hline
\end{tabular}

Source: [12, 13].

TABLE 2: Key hydroenergy statistics.

\begin{tabular}{lccccccc}
\hline & Unit/year & 1990 & 1995 & 2000 & 2005 & 2010 & 2015 \\
\hline Primary energy supply & $\mathrm{kTOE}$ & 9733 & 11022 & 13462 & 17243 & 20663 & 25968 \\
Hydropower share & $\mathrm{kTOE}$ & 133 & 132 & 184 & 153 & 232 & 181 \\
& $\%$ & 1.37 & 1.20 & 1.37 & 0.89 & 1.23 & 0.70 \\
\hline
\end{tabular}

Source: [12].

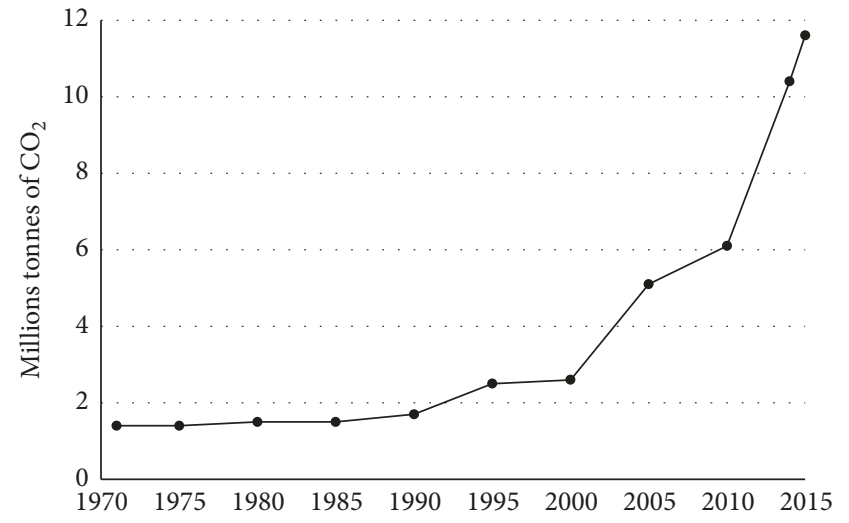

Figure 5: $\mathrm{CO}_{2}$ emissions in Tanzania from 1971 to 2015 [12, 13].

which a total of 9733 kTOE and 13,462 kTOE were supplied, respectively. The share of hydropower declined in the years 2001 and 2003 reaching $0.89 \%$ in 2005 as a result of a prolonged period of drought as explained in Loisulie [88] and Malley [95].

5.3. The Role of Hydropower within Electricity Generation. The electricity demand in Tanzania is met through various resources primarily categorized as renewable and nonrenewable. Renewable energy resources currently meeting electricity demand in the country include hydro, solar, biomass, wind, and in future geothermal which is still under development stages whereas nonrenewable energy sources are primarily petroleum, coal, and natural gas $[2,7]$. Tanzanian hydropower generation for 2015 was estimated at $6,295 \mathrm{GWh}$ or $33.5 \%$ of total electricity generation as opposed to $1628 \mathrm{GWh}$ or $95 \%$ in 1990 based on International Energy Agency (IEA) data [12]. The roles of hydropower and other resources within electricity generation are depicted in

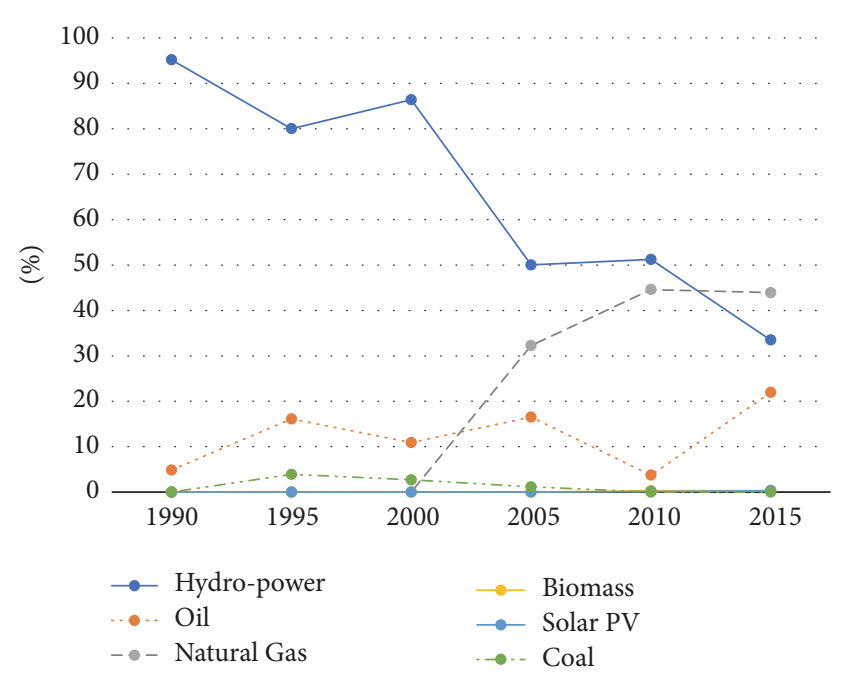

FIGURE 6: The role of hydropower within electricity generation 1990-2015 [12].

Figure 6. Over the period from 1990 to 2015, hydropower generation has tended to rise and fall irregularly, exhibiting varying water availability due to phases of below or above average rainfall. Nevertheless, the share of hydropower in total electricity generation has increasingly declined over the period from 1990 to 2015 reflecting the higher growth of alternative forms of electricity generating resources. For example, in 1990, there were only two alternative forms of electricity generation, namely, hydropower and oil as opposed to five alternative forms in 2015.

The composition of energy resources for electricity generation has changed significantly after natural gas begun to claim its market share. As it can be seen in Figure 6, the influence of natural gas into the total electricity generation became apparent after the year 2000s and its share increased 
sharply to date compensating the decline in hydropower generations. Thermal-power generations using natural gas has recently been the largest generator of electricity in Tanzania, commanding for approximately $44 \%$ of total generation in 2015 [12]. A similar situation is also observed for oil products share into electricity generation. Observations show that imported oil had a significant contribution of around $22 \%$ to the total electricity generation in 2015 as opposed to approximately $10 \%$ in 2000 , and then introduction of natural gas into the market instigated this contribution to gradually decrease to around $4 \%$ in 2010 . The statistics indicate that since 2000, utilization of fossil fuels specifically natural gas for electricity generation has increased considerably in Tanzania.

\subsection{GHG Emissions Reduction: The Future Roles of Hydro-} power. Hydropower potential in the country has previously been affected by the decrease in an overall annual rainfall accompanied with intensified and prolonged dry and wet spells weather events, making the predictability of seasonal weather patterns more challenging $[88,96]$. Kichonge et al. [28] have planned using Model for Energy Supply Strategy Alternatives and their General Environmental Impact (MESSAGE) which is bottom-up modeling approach to two scenarios both for future resource supply mix. Modeling period was between 2010 and 2040 of which supply projections have previously named as dry-weather and business as usual (BAU) scenarios, respectively. Dry-weather scenario, introduced for the purpose of investigating possible energy resources supply mix under extreme weather conditions, revealed that, with less availability of hydropower at least $20 \%$ of the existing total potential, the electricity generations swing heavily to thermal-power plants technologies. In dryweather scenario, higher shares of electricity generation came from coal and natural gas power plants. The enormousness at which hydropower has in the generation of electricity is huge and needs special attention for planners and policy makers [28].

The shift to fossil fuels power plant technologies goes in line with the increase in the expenditure for primary energy supply. Moreover, less availability of hydropower reveals huge impact in the environment including the increase of GHG emissions. Demonstration over the immense potential of renewable energy sources in reduction of GHG emissions levels over the entire modeling period between BAU and dry-weather scenarios is depicted in Figure 7. The role of hydropower to the total share in electricity generation is expected to decrease due to first increases in the total energy demand while the current potential remains fixed and second firm measures being not taken to fully exploit existing potential as proposed in a number of studies.

5.5. Installed Hydropower Generation Capacity. The largest hydropower plant in Tanzania is Kidatu with a capacity of $204 \mathrm{MW}$, which is somehow mid-sized under international standards. The second largest hydropower plant is named as Kihansi with installed capacity of $180 \mathrm{MW}$. Both these hydropower plants are located in the Rufiji river basin $[1,7]$. The total installed hydropower capacity is $561.843 \mathrm{MW}$ of which $82.7 \%$ have been installed in Rufiji basin. Majority

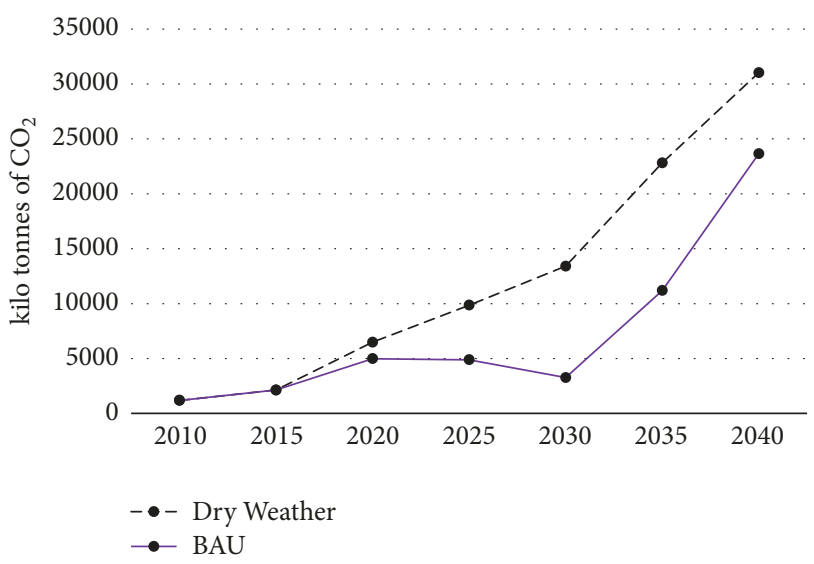

Figure 7: $\mathrm{CO}_{2}$ emissions projections scenarios [28].

of Tanzanian hydropower plants are now more than 50 years old as depicted in Table 3 [2]. In order for these hydropower plants to continue to offer services as planned will require refurbishment. Hydropower plants refurbishment will require significant expenditure on infrastructure, including the replacement and repair of vital parts.

5.6. Hydropower Development Projects in Tanzania. Hydropower remains as important renewable energy option for Tanzania due to its useful characteristics rarely found in other sources of energy such as being clean and less impactful on the environment, as well as being a cheap and domestically available [28, 97, 98]. Hydropower development has become a focal point of consideration in recent years to satisfy the energy demand and achieve the country's sustainable socioeconomic development goals as proposed in its Vision 2025 [48]. Hydropower is considered as a link to a shift into more sustainable energy sources and therefore identified as environmentally friendly feasible option pending that the transition to a more sustainable energy producing technology is realized $[99,100]$.

Based on the facts described, Tanzania, in her quest to meet its Vision 2025 which emphasizes the need for socioeconomic growth supported by a reliable and affordable energy supply as important feature for the development process [48], has identified and proposed twenty-three hydropower projects with nearly $4,765 \mathrm{GW}$ capacity as future power development options [2, 14]. Some of these options are currently in planning phase or in different implementation stages, the largest being Steigler's Gorge located in Rufiji river basin $[2,14]$. The Stiegler's Gorge hydropower project is still in its initial stages of implementation and is expected to have an installed capacity of 1,048 MW in phase I and 1,048 MW in phase II. The driving motives behind the Stiegler's Gorge and other projects aim at sustaining the projected increase in electricity demand while keeping environment clean for future generations $[1,8]$.

\section{Small Hydropower Sector Overview}

Small hydropower plants continue to play an important role in rural areas electrification. The projected potential for small 
TABLE 3: Installed hydropower generation characteristics in Tanzania.

\begin{tabular}{|c|c|c|c|c|c|c|c|c|}
\hline Plant name & Hale & $\begin{array}{l}\text { Nyumba ya } \\
\text { Mungu }\end{array}$ & $\begin{array}{c}\text { New Pangani } \\
\text { Falls }\end{array}$ & Kidatu & Mtera & Uwemba & Kihansi & $\begin{array}{l}\text { Mwenga } \\
\text { Hydro Ltd. }\end{array}$ \\
\hline River basin & & Pangani & & & & Rufiji & & \\
\hline Generation type & Run-off river & reservoir & Run-off river & \multicolumn{2}{|c|}{ Reservoir } & \multicolumn{3}{|c|}{ Run-off river } \\
\hline Installation year & 1964 & 1968 & 1995 & $1975 / 1980$ & 1988 & 1991 & $1999 / 2000$ & 2012 \\
\hline $\begin{array}{l}\text { Installed } \\
\text { capacity (MW) }\end{array}$ & 21 & 8 & 68 & 204 & 80 & 0.843 & 180 & 4 \\
\hline $\begin{array}{l}\text { Plant discharge } \\
\left(\mathrm{m}^{3}\right)\end{array}$ & 45 & 42.5 & 45 & 140 & 96 & N/A & 23.76 & 8 \\
\hline $\begin{array}{l}\text { Annual } \\
\text { generation } \\
\text { (GWh) }\end{array}$ & 36.11 & 21.53 & 137.2 & 558.34 & 166.68 & 2.3 & 793.49 & 17.10 \\
\hline $\begin{array}{l}\text { Reservoir active } \\
\text { storage }\left(10^{6} \mathrm{~m}^{3}\right)\end{array}$ & 0 & 600 & 0.8 & 125 & 3.2 & N/A & 1 & - \\
\hline Turbine type & \multicolumn{5}{|c|}{ Francis-Vertical } & N/A & Pelton & Francis \\
\hline Plant factor (\%) & 20 & 31 & 23 & 31 & 24 & 31 & 50 & 49 \\
\hline
\end{tabular}

Source: $[2,14]$.

hydropower generation with capacities of less than $10 \mathrm{MW}$ in Tanzania is estimated at $315 \mathrm{MW}[101,102]$. The information gathered for this review shows that the exploited potential is estimated at only $25 \mathrm{MW}$ which is approximately $8 \%$ of the total potential with the positive projections to its increase rising. However, a good number of small hydropower potential sites are located in remote rural settings where the national grid does not spread, so most of these sites would be best utilized to supply power to rural areas. The utilization of small hydropower potential could boost electricity access level even higher in rural area as nearly all regions [103, 104]. Map of 75 potential small hydropower sites in Tanzania is depicted in Figure 8 [29]. As seen in Figure 8, most of the promising small hydropower potentials are located in areas close to the main lakes such as Nyasa, Tanganyika, and Victoria. Most of the central and coastal parts of the country have so far not identified with potential small hydropower sites.

Globally, medium- and large-scale hydropower plants have become much riskier for investment attraction as a result of climate challenges among other issues, thus calling for a shift of focus into small hydropower generation [4]. Climate change has negatively impacted ability of large- and medium-scale hydropower plants to provide stable power production in some areas Tanzania inclusive [84, 88, 89]. In such conditions, adaptation measures are necessary such as using small-scale hydropower generation to improve the performance of the reduced flow not suitable for large-scale power plants. The projected challenges as a result of rainfall decrease as seen in McSweeney et al. [38], MEM [7], and Paavola [85] provide a perfect environment for increased development of hydropower resources with the focus on small hydropower plants whose technoeconomic demands can be served by investors with relative less difficulties.

Small hydropower plants are considered as a well functional resource for the sustainable development and therefore suitable solution to all the downsides of large- and mediumscale hydropower projects [105, 106]. Small hydropower technologies are largely "run-off river" and hence do not

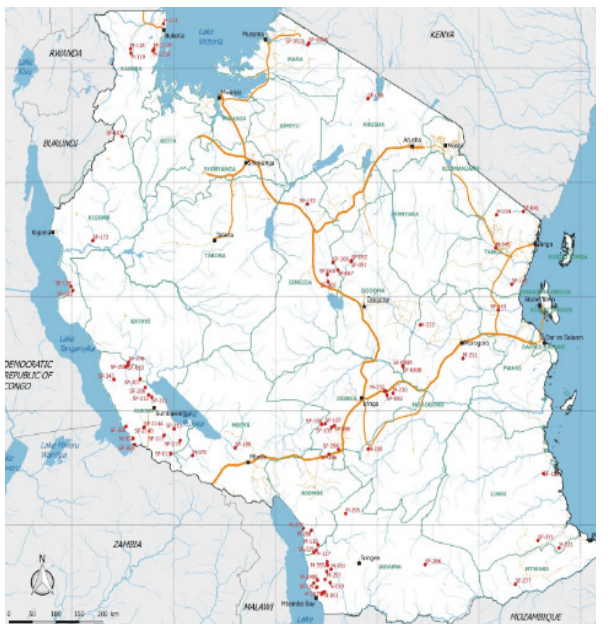

- Promising potential small hydro-power site

FIgURE 8: Potential small renewable power sites in Tanzania [29].

require construction of storage facilities and are therefore cost-effective which implies that they have got minimal and ignorable environmental challenges [4, 107, 108]. Moreover, small hydropower plants utilize only part of the available water in rivers, making them less susceptible to fluctuations in the water quantities due to climate changes [4, 109].

\section{Conclusion}

It is clear that Tanzania, as a lower income country determined to achieve middle-income status, needs, amid other actions, to advance its electricity supply through utilization of locally available resources to meet her ever growing energy demands. Tanzania is a country with huge water resources potential which possesses sufficient and suitable characteristics to develop and maintain sustainable hydropower generation from small to large scale. Continuing exploiting 
water resources for hydropower projects will bring on board several significant socioeconomic benefits to the country which might not have been possible with other nonrenewable sources to achieve even the modest environmental goals. The country's unexploited hydropower potential needs to be well thought-out in the future energy mix. However, due to numerous climate challenges sometimes affecting largeand medium-scale hydropower projects, the review explored and determined the key roles in which small hydropower projects can play in electricity generation and conservation of environment specifically mitigation of GHG emissions effects. Generally, the review concludes that, because of the country geographical location and the fact that hydropower potential is the main clean domestic energy resource option, there are substantial benefits to promote its developments to ensure a more sustainable growth pathway in electricity generation.

\section{Conflicts of Interest}

The author declares that there are no conflicts of interest regarding the publication of this paper.

\section{References}

[1] MEM, Electricity Supply Industry Reform Strategy and Roadmap 2014 - 2025, Ministry of Energy and Minerals, Dar es Salaam, Tanzania, 2014

[2] MEM, Power System Master Plan 2016 Update, Ministry of Energy and Minerals, Dar es Salaam, Tanzania, 2016.

[3] A. Evans, V. Strezov, and T. Evans, "Comparing the sustainability parameters of renewable, nuclear and fossil fuel electricity generation technologies," in World Energy Council for Sustainable Energy, Congress Papers, World Energy Council, Montréal, Canada, 2010.

[4] B. Dursun and C. Gokcol, "The role of hydroelectric power and contribution of small hydropower plants for sustainable development in Turkey," Journal of Renewable Energy, vol. 36, no. 4, pp. 1227-1235, 2011.

[5] K. Kaygusuz, "Hydropower and the World's Energy Future," Energy Sources, vol. 26, no. 3, pp. 215-224, 2004.

[6] O. Ellabban, H. Abu-Rub, and F. Blaabjerg, "Renewable energy resources: current status, future prospects and their enabling technology," Renewable \& Sustainable Energy Reviews, vol. 39, pp. 748-764, 2014.

[7] MEM, Scaling Up Renewable Energy Programme (SREP) Investment Plan for Tanzania, Ministry of Energy and Minerals - United Republic of Tanzania, 2013, https://www.climateinvestmentfunds.org/sites/default/files/meeting-documents/srep_tanzania_investment_plan_design.pdf.

[8] B. Kichonge, G. R. John, I. S. Mkilaha, and H. Sameer, "Modelling of future energy demand for Tanzania," Journal of Energy Technologies and Policy, vol. 4, no. 7, pp. 16-31, 2014.

[9] TANESCO, Provision of Financial Advisory and Modeling Services to TANESCO, Tanzania Electric Supply Company Limited (TANESCO), Dar es Salaam, Tanzania, 2010.

[10] S. Kihwele, K. Hur, and A. Kyaruzi, "Visions, scenarios and action plans towards next generation tanzania power system," Energies, vol. 5, no. 10, pp. 3908-3927, 2012.
[11] URT, The Tanzania Long Term Perspective Plan (2011-2025) The Roadmap to A Middle Income Country, P. S. O.-P. Commission, Ed., URT, Dar es Salaam, Tanzania, 2012.

[12] IEA, Energy Balances of Non-OECD Countries, International Energy Agency, 2017, http://www.iea.org/statistics/statisticssearch/report/?year=2015\&amp;country=TANZANIA\& product $=$ Balances.

[13] IEA, CO2 Emissions from Fuel Combustion Highlights, International Energy Agency Paris, 2017.

[14] MEM, Power System Master Plan 2012 Update, Ministry of Energy and Minerals, Dar es Salaam, Tanzania, 2012.

[15] G. W. Frey and D. M. Linke, "Hydropower as a renewable and sustainable energy resource meeting global energy challenges in a reasonable way," Energy Policy, vol. 30, no. 14, pp. 1261-1265, 2002.

[16] T. Couture and Y. Gagnon, "An analysis of feed-in tariff remuneration models: Implications for renewable energy investment," Energy Policy, vol. 38, no. 2, pp. 955-965, 2010.

[17] S. Bilgen, K. Kaygusuz, and A. Sari, "Renewable energy for a clean and sustainable future," Energy Sources, vol. 26, no. 12, pp. 1119-1129, 2004.

[18] N. L. Panwar, S. C. Kaushik, and S. Kothari, "Role of renewable energy sources in environmental protection: a review," Renewable \& Sustainable Energy Reviews, vol. 15, no. 3, pp. 1513-1524, 2011.

[19] I. Dincer, "Renewable energy and sustainable development: a crucial review," Renewable \& Sustainable Energy Reviews, vol. 4, no. 2, pp. 157-175, 2000.

[20] E. Martinot, A. Chaurey, D. Lew, J. R. Moreira, and N. Wamukonya, "Renewable energy markets in developing countries," Annual Review of Environment and Resources, vol. 27, pp. 309-348, 2002.

[21] H. Lund, "Renewable energy strategies for sustainable development," Energy, vol. 32, no. 6, pp. 912-919, 2007.

[22] M.Z. Jacobson and M. A. Delucchi, "Providing all global energy with wind, water, and solar power, part I: technologies, energy resources, quantities and areas of infrastructure, and materials," Energy Policy, vol. 39, no. 3, pp. 1154-1169, 2011.

[23] K. Kaygusuz and A. Sarı, "Renewable energy potential and utilization in Turkey," Energy Conversion and Management, vol. 44, no. 3, pp. 459-478, 2003.

[24] H. Altinbilek, "Hydropower for sustainable development," International Journal on Hydropower and Dams, vol. 11, no. 5, pp. 6569, 2004.

[25] H. J. Hoag and M.-B. Öhman, "Turning water into power: Debates over the development of tanzania's rufiji river basin, 1945-1985," Technology and Culture, vol. 49, no. 3, pp. 624-651, 2008.

[26] J. King, C. Brown, J. Turpie et al., Hydrology and System Analysis. Volume 2 of 2: Development and Application of a System Model for the Pangani River Basin. PBWB/IUCN. 2008, Basin Delineation Report, Pangani Basin Water Board, Moshi and IUCN Eastern and Southern Africa Regional Programme, Nairobi, Kenya, 2008.

[27] M. V. Mdemu and T. Francis, Productivity of water in large rice (paddy) irrigation schemes in the upper catchment of the Great Ruaha River Basin, Tanzania, Water Resources Planning, Development and Management. InTech, 2013.

[28] B. Kichonge, G. R. John, and I. S. N. Mkilaha, "Modelling energy supply options for electricity generations in Tanzania," Journal of Energy in Southern Africa, vol. 26, no. 3, pp. 41-57, 2015. 
[29] World-Bank, Small Hydro Resource Mapping in Tanzania: Phase 1 Report, World Bank Group, Washington, DC, USA, 2015.

[30] G. H. Brundtland, Report of the World Commission on environment and development:" our common future, United Nationspp, 1987.

[31] R. W. Kates, T. M. Parris, and A. A. Leiserowitz, "What is sustainable development? Goals, indicators, values, and practice," Environment International, vol. 47, no. 3, pp. 8-21, 2005.

[32] A. M. Omer, "Energy, environment and sustainable development," Renewable \& Sustainable Energy Reviews, vol. 12, no. 9, pp. 2265-2300, 2008.

[33] A. Pegels, "Renewable energy in South Africa: Potentials, barriers and options for support," Energy Policy, vol. 38, no. 9, pp. 4945-4954, 2010.

[34] T. H. Oh, S. Y. Pang, and S. C. Chua, "Energy policy and alternative energy in Malaysia: Issues and challenges for sustainable growth," Renewable \& Sustainable Energy Reviews, vol. 14, no. 4, pp. 1241-1252, 2010.

[35] S. Dudhani, A. K. Sinha, and S. S. Inamdar, "Assessment of small hydropower potential using remote sensing data for sustainable development in India," Energy Policy, vol. 34, no. 17, pp. 31953205, 2006.

[36] D. Verschuren, J. S. Sinninghe Damsté, J. Moernaut et al., "Half-precessional dynamics of monsoon rainfall near the East African Equator," Nature, vol. 462, no. 7273, pp. 637-641, 2009.

[37] Z. Owiti, "Spatial distribution of rainfall seasonality over East Africa," Journal of Geography and Regional Planning, vol. 5, no. 15, pp. 409-421, 2012.

[38] C. McSweeney, M. New, and G. Lizcano, "Climate change country profiles: Tanzania," 2010, http://www.geog.ox.ac.uk/ research/climate/projects/undp-cp/index.html?country=Tanzania\&d1=Reports.

[39] FAO, "AQUASTAT website. Food and Agriculture Organization of the United Nations (FAO)," 2016, http://www.fao.org/nr/ water/aquastat/countries_regions/TZA/.

[40] P. H. Gleick, “The human right to water," Water Policy, vol. 1, no. 5, pp. 487-503, 1998.

[41] D. Grey and C. W. Sadoff, "Sink or Swim? Water security for growth and development," Water Policy, vol. 9, no. 6, pp. 545571, 2007.

[42] C. S. Sokile, W. Mwaruvanda, and B. Van Koppen, "Integrated water resource management in Tanzania: Interface between formal and informal institutions," in Proceedings of the conference African Water Laws: Plural Legislative Frameworks for Rural Water Management in Africa, pp. 26-28, 2005.

[43] C. S. Sokile, J. J. Kashaigili, and R. M. J. Kadigi, "Towards an integrated water resource management in Tanzania: The role of appropriate institutional framework in Rufiji Basin," Physics and Chemistry of the Earth, vol. 28, no. 20-27, pp. 1015-1023, 2003.

[44] F. P. Maganga, H. L. Kiwasila, I. H. Juma, and J. A. Butterworth, "Implications of customary norms and laws for implementing IWRM: Findings from Pangani and Rufiji basins, Tanzania," Physics and Chemistry of the Earth, vol. 29, no. 15-18, pp. 13351342, 2004.

[45] M. L. Mul, R. K. Mutiibwa, S. Uhlenbrook, and H. H. G. Savenije, "Hydrograph separation using hydrochemical tracers in the Makanya catchment, Tanzania," Physics and Chemistry of the Earth, vol. 33, no. 1-2, pp. 151-156, 2008.

[46] F. P. Maganga, "Incorporating Customary Laws in Implementation of IWRM: Some Insights from Rufiji River Basin, Tanzania," in Proceedings of the 3rd Waternet/WARFSA Symposium:
Integrating Water Supply \& Water Demand for Sustainable Use of Water Resources, White Sands Hotel, Dar es Salaam, Tanzania, 2002.

[47] URT, National Water Policy, Government Printer, 2002.

[48] URT, The Tanzania Development Vision 2025, Dar Salaam: President's Office, 1999.

[49] R. Giné and A. Pérez-foguet, "Sustainability assessment of national rural water supply program in Tanzania," Natural Resources Forum, vol. 32, no. 4, pp. 327-342, 2008.

[50] B. Van Koppen, C. S. Sokile, N. Hatibu, B. A. Lankford, H. Mahoo, and P. Z. Yanda, Formal water rights in rural Tanzania: Deepening the dichotomy? IWMIpp, 2004.

[51] T. Franks, B. Lankford, and M. Mdemu, "Managing water amongst competing uses: The Usangu Wetland In Tanzania," Irrigation and Drainage, vol. 53, no. 3, pp. 277-286, 2004.

[52] B. A. Lankford, S. Tumbo, and K. Rajabu, "Water competition, variability and river basin governance: A critical analysis of the great Ruaha River, Tanzania," River Basin Trajectories: Societies, Environments and Development, pp. 171-195, 2009.

[53] S. Gössling, "The consequences of tourism for sustainable water use on a tropical island: Zanzibar, Tanzania," Journal of Environmental Management, vol. 61, no. 2, pp. 179-191, 2001.

[54] R. G. Taylor, M. C. Todd, L. Kongola et al., "Evidence of the dependence of groundwater resources on extreme rainfall in East Africa," Nature Climate Change, vol. 3, no. 4, pp. 374-378, 2013.

[55] J. D. Milliman and K. L. Farnsworth, River Discharge to the Coastal Ocean: A Global Synthesis, Cambridge University Presspp, 2013.

[56] K. T. Kabaka and F. Gwangombe, "Challenges in small hydropower development in Tanzania: rural electrification perspective," in Proceedings of the International Conference on Small Hydropower-Hydro, pp. 22-24, Kandy, Sri Lanka, 2007.

[57] B. Fisher, K. Kulindwa, I. Mwanyoka, R. K. Turner, and N. D. Burgess, "Common pool resource management and PES: Lessons and constraints for water PES in Tanzania," Ecological Economics, vol. 69, no. 6, pp. 1253-1261, 2010.

[58] H. C. Komakech, P. Van der Zaag, and B. Van Koppen, “The last will be first: Water transfers from agriculture to cities in the Pangani River Basin, Tanzania," Water Alternatives, vol. 5, no. 3, pp. 700-720, 2012.

[59] F. P. Maganga, J. A. Butterworth, and P. Moriarty, "Domestic water supply, competition for water resources and IWRM in Tanzania: A review and discussion paper," Physics and Chemistry of the Earth, vol. 27, no. 11-22, pp. 919-926, 2002.

[60] Y. Bhatt, D. Bossio, E. Enfors et al., Smallholder System Innovations in Integrated Watershed Management (SSI): Strategies of Water for Food And Environmental Security in Drought-Prone Tropical and Subtropical Agro-Ecosystems, IWMIpp, 2006.

[61] M. J. Mbonile, "Migration and intensification of water conflicts in the Pangani Basin, Tanzania," Habitat International, vol. 29, no. 1, pp. 41-67, 2005.

[62] H. Komakech, B. van Koppen, H. Mahoo, and P. van der Zaag, "Pangani River Basin over time and space: On the interface of local and basin level responses," Agricultural Water Management, vol. 98, no. 11, pp. 1740-1751, 2011.

[63] PBWB/IUCN, "Pangani River System - Future of the Basin Report. Moshi, Tanzania," PBWB and Nairobi, Kenya: IUCN Eastern and Southern Africa Regional Programme. 2011, https://portals.iucn.org/library/sites/library/files/documents/ 2011-015.pdf. 
[64] J. Rockström, C. Folke, L. Gordon et al., "A watershed approach to upgrade rainfed agriculture in water scarce regions through Water System Innovations: An integrated research initiative on water for food and rural livelihoods in balance with ecosystem functions," Physics and Chemistry of the Earth, vol. 29, no. 15-18, pp. 1109-1118, 2004.

[65] H. Hellar-Kihampa, K. de Wael, E. Lugwisha, and R. van Grieken, "Water quality assessment in the Pangani River basin, Tanzania: Natural and anthropogenic influences on the concentrations of nutrients and inorganic ions," International Journal of River Basin Management, vol. 11, no. 1, pp. 55-75, 2013.

[66] IEA, Energy Balances of Non-OECD Countries 2012, International Energy Agency, 2012.

[67] MEM, Joint Energy Sector Review (JESR) 2012/13 - Tanzania, Ministry of Energy and Minerals, Dar es Salaam, Tanzania, 2013.

[68] H. Sadiki, Water Resources Management Challenges in Pangani Basin, Ministry of Water and Irrigation-World Bank Institute cum Training on IWRM, Tanzania, Tanzania, 2008.

[69] J. Turpie, Y. Ngaga, and F. Karanja, "A preliminary Economic Assessment of water Resources of Pangani River Basin, Tanzania," in Economic Value, Incentives for Sustainable Use and Mechanisms for financing management, IUCN-East Africa Region Office and Pangani Basin Water Office, 2003.

[70] R. B. B. Mmalyosi, "Resource potentials of the Rufiji River Basin, Tanzania," AMBIO, vol. 19, no. 1, pp. 16-20, 1990.

[71] S. Mwakalila, "Water resource use in the Great Ruaha Basin of Tanzania," Physics and Chemistry of the Earth, vol. 30, no. 11-16, pp. 903-912, 2005.

[72] J. J. Kashaigili, M. Mccartney, and H. F. Mahoo, "Estimation of environmental flows in the Great Ruaha River Catchment, Tanzania," Physics and Chemistry of the Earth, vol. 32, no. 15-18, pp. 1007-1014, 2007.

[73] R. M. J. Kadigi, N. S. Y. Mdoe, G. C. Ashimogo, and S. Morardet, "Water for irrigation or hydropower generation?Complex questions regarding water allocation in Tanzania," Agricultural Water Management, vol. 95, no. 8, pp. 984-992, 2008.

[74] B. A. Lankford, "Red routes on blue rivers: Strategic water management for the Ruaha river basin, Tanzania," International Journal of Water Resources Development, vol. 17, no. 3, pp. 427444, 2001.

[75] B. Lankford and N. Hepworth, "The cathedral and the bazaar: Monocentric and polycentric river basin management," Water Alternatives, vol. 3, no. 1, pp. 82-101, 2010.

[76] H. E. Igbadun, H. F. Mahoo, A. K. P. R. Tarimo, and B. A. Salim, "Crop water productivity of an irrigated maize crop in Mkoji sub-catchment of the Great Ruaha River Basin, Tanzania," Agricultural Water Management, vol. 85, no. 1-2, pp. 141-150, 2006.

[77] M. P. McCartney, B. A. Lankford, and H. Mahoo, Agricultural water management in a water stressed catchment: Lessons from the RIPARWIN project, IWMIpp, 2007.

[78] J. J. Kashaigili, "Impacts of land-use and land-cover changes on flow regimes of the Usangu wetland and the Great Ruaha River, Tanzania," Physics and Chemistry of the Earth, vol. 33, no. 8-13, pp. 640-647, 2008.

[79] B. Lankford, B. Van Koppen, T. Franks, and H. Mahoo, "Entrenched views or insufficient science? Contested causes and solutions of water allocation; insights from the Great Ruaha River Basin, Tanzania," Agricultural Water Management, vol. 69, no. 2, pp. 135-153, 2004.
[80] J. J. Kashaigili, R. M. J. Kadigi, B. A. Lankford, H. F. Mahoo, and D. A. Mashauri, "Environmental flows allocation in river basins: Exploring allocation challenges and options in the Great Ruaha River catchment in Tanzania," Physics and Chemistry of the Earth, vol. 30, no. 11-16, pp. 689-697, 2005.

[81] R. M. Kadigi, N. S. Mdoe, B. A. Lankford, and S. Morardet, “The value of water for irrigated paddy and hydropower generation in the Great Ruaha, Tanzania," in Proceedings of the East Africa Integrated River Basin Management Conference, pp. 265-278, 2005.

[82] S. Mwakalila, "Opportunities and challenges for sustainable water resources management in Tanzania," The Geographical Journal, vol. 174, no. 2, pp. 154-157, 2008.

[83] H. Middelkoop, K. Daamen, D. Gellens et al., "Impact of climate change on hydrological regimes and water resources management in the Rhine basin," Climatic Change, vol. 49, no. 1-2, pp. 105-128, 2001.

[84] C. S. Kaunda, C. Z. Kimambo, and T. K. Nielsen, "Potential of small-scale hydropower for electricity generation in SubSaharan Africa," ISRN Renewable Energy, vol. 2012, Article ID 132606, 15 pages, 2012.

[85] J. Paavola, "Livelihoods, vulnerability and adaptation to climate change in Morogoro, Tanzania," Environmental Science \& Policy, vol. 11, no. 7, pp. 642-654, 2008.

[86] P. Mukheibir, "Possible climate change impacts on large hydroelectricity schemes in Southern Africa," Journal of Energy in Southern Africa, vol. 18, no. 1, pp. 4-9, 2007.

[87] L. Beck and T. Bernauer, "How will combined changes in water demand and climate affect water availability in the Zambezi river basin?" Global Environmental Change, vol. 21, no. 3, pp. 1061-1072, 2011.

[88] S. Loisulie, Vulnerability of the Tanzanian Hydropower Production to Extreme Weather Events, Sokoine University of Agriculture Faculty of Science, 2010, http://indico.ictp.it/event/a09141/ session/11/contribution/7/material/0/0.pdf.

[89] P. Mukheibir, "Potential consequences of projected climate change impacts on hydroelectricity generation," Climatic Change, vol. 121, no. 1, pp. 67-78, 2013.

[90] D. Kumar and S. S. Katoch, "Sustainability suspense of small hydropower projects: A study from western Himalayan region of India," Journal of Renewable Energy, vol. 76, pp. 220-233, 2015.

[91] C. Zarfl, A. E. Lumsdon, J. Berlekamp, L. Tydecks, and K. Tockner, "A global boom in hydropower dam construction," Aquatic Sciences, vol. 77, no. 1, pp. 161-170, 2015.

[92] G. Ardizzon, G. Cavazzini, and G. Pavesi, "A new generation of small hydro and pumped-hydro power plants: Advances and future challenges," Renewable \& Sustainable Energy Reviews, vol. 31, pp. 746-761, 2014.

[93] K. O. Winemiller, P. B. McIntyre, L. Castello et al., "Balancing hydropower and biodiversity in the Amazon, Congo, and Mekong," Science, vol. 351, no. 6269, pp. 128-129, 2016.

[94] Z. Girma, “Techno-Economic Feasibility of Small Scale Hydropower in Ethiopia: The Case of the Kulfo River, in Southern Ethiopia," Journal of Renewable Energy, vol. 2016, Article ID 8037892, 12 pages, 2016.

[95] Z. Malley, Climate change and water resources for energy generation in Tanzania, 2011.

[96] M. Y. Mkonda and X. He, "Are rainfall and temperature really changing? Farmer's perceptions, meteorological data, and policy implications in the Tanzanian semi-arid zone," Sustainability, vol. 9, no. 8, article no. 1412, 2017. 
[97] B. M. Lyimo, Improving energy resillience in Tanzania. Helio International, 2007.

[98] J. Kiwia, "River resources towards Sustainable Development of Tanzania.: A contribution of Hydropower to the energy security in Tanzania: Case study, Rufiji River basin,” 2013.

[99] R. Sternberg, "Hydropower's future, the environment, and global electricity systems," Renewable \& Sustainable Energy Reviews, vol. 14, no. 2, pp. 713-723, 2010.

[100] J. Liu, J. Zuo, Z. Sun, G. Zillante, and X. Chen, "Sustainability in hydropower development - A case study," Renewable \& Sustainable Energy Reviews, vol. 19, pp. 230-237, 2013.

[101] C. F. Mhilu, "Small-scale hydro electric power potential in Tanzania," East African Journal of Engineering, vol. 7, no. 1, pp. 15-22, 2004.

[102] H. Liu, D. Masera, and L. Esser, World Small Hydropower Development Report 2013, International Center on Small Hydro Power, United Nations Industrial Development Organization, 2013.

[103] E. Michael, Institutional design and practices for sustainable decentralised energy systems development for rural electrification. the case of isolated mini-hydro power systems developed by catholic church mission, njombe diocese, tanzania, vol. 122, University of Twente, Enschede, Netherlands, 2008.

[104] M. Hankins, Target Market Analysis:Tanzania's Small-Hydro Energy Market, GTZ, 2009.

[105] A. Evans, V. Strezov, and T. J. Evans, "Assessment of sustainability indicators for renewable energy technologies," Renewable \& Sustainable Energy Reviews, vol. 13, no. 5, pp. 1082-1088, 2009.

[106] R. Prakash and I. K. Bhat, "Energy, economics and environmental impacts of renewable energy systems," Renewable \& Sustainable Energy Reviews, vol. 13, no. 9, pp. 2716-2721, 2009.

[107] O. Paish, "Small hydro power: technology and current status," Renewable \& Sustainable Energy Reviews, vol. 6, no. 6, pp. 537556, 2002.

[108] P. Purohit, "Small hydro power projects under clean development mechanism in India: A preliminary assessment," Energy Policy, vol. 36, no. 6, pp. 2000-2015, 2008.

[109] H. Nautiyal, S. K. Singal, Varun, and A. Sharma, "Small hydropower for sustainable energy development in India," Renewable \& Sustainable Energy Reviews, vol. 15, no. 4, pp. 20212027, 2011. 

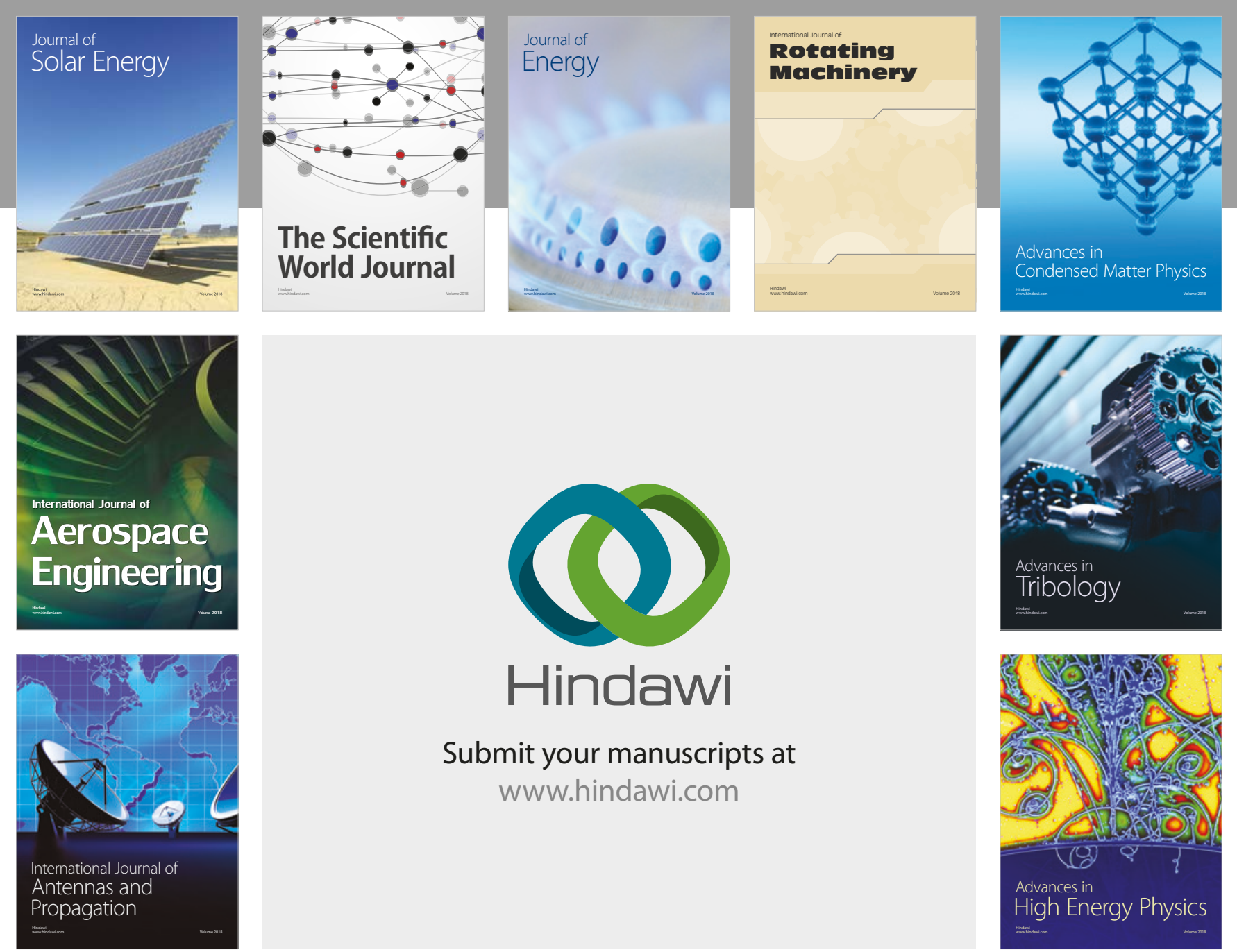

Submit your manuscripts at

www.hindawi.com
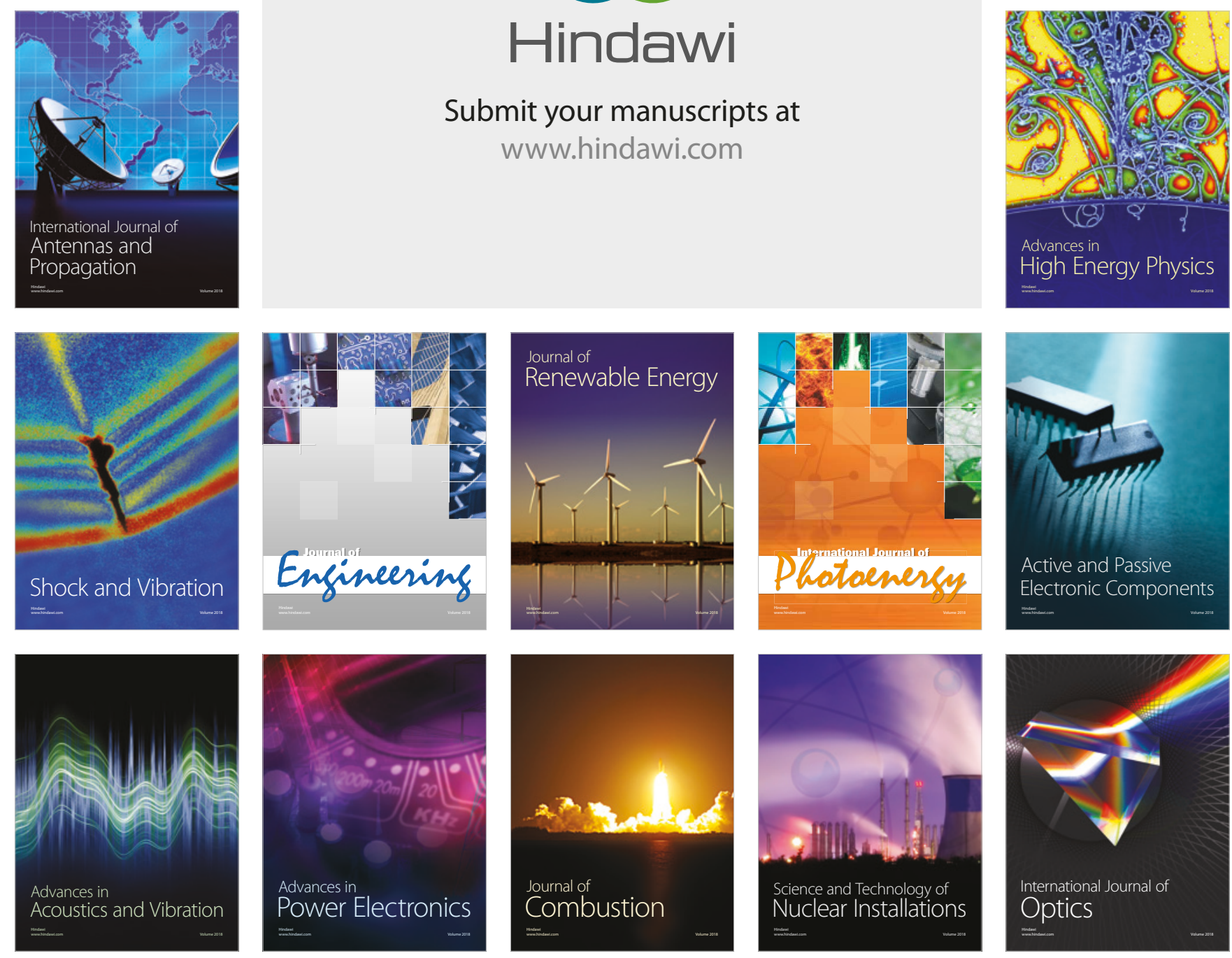